\title{
Analysis of the Current Situation of Cross-Border Higher Education in the Background of Internationalization
}

\author{
Dan Xu \\ Faculty of International Studies, Henan Normal University, Xinxiang, China \\ Email: x_dan@foxmail.com
}

How to cite this paper: Xu, D. (2019) Analysis of the Current Situation of Cross-Border Higher Education in the Background of Internationalization. Open Journal of Social Sciences, 7, 132-137. https://doi.org/10.4236/jss.2019.72010

Received: January 19, 2019

Accepted: February 12, 2019

Published: February 15, 2019

Copyright $\odot 2019$ by author(s) and Scientific Research Publishing Inc. This work is licensed under the Creative Commons Attribution International License (CC BY 4.0).

http://creativecommons.org/licenses/by/4.0/

\section{cc) (i) Open Access}

\begin{abstract}
The internationalization of higher education has become the mainstream trend of the development of the world education system. Since entering the period of knowledge education, cross-border higher education has gradually become one of the research topics of the teachers of higher education. The policy system for the internationalization of China's higher education is constantly improving, and the number of international students is increasing, and great progress has been made in many aspects. This paper takes knowledge education as the background of the subject research, and elaborates the development status of cross-border higher education work based on practical problems. It is expected to help the teachers in the industry to better improve the actual teaching standards, and thus promote the development of China's higher education internationalization.
\end{abstract}

\section{Keywords}

Internationalization, Cross-Border Higher Education, Internet Information, Teaching Level

\section{Introduction}

Since the beginning of the 21st century, the Chinese government has actively promoted the development of higher education internationalization in colleges and universities, and has achieved stage results. However, the internationalization of higher education starts late, and the understanding of the internationalization of higher education is not deep and comprehensive, and there lacks the rich internationalization experience of higher education, and there are still many tasks in China that need to be further strengthened and improved [1]. The re- 
search on cross-border higher education topics can be traced back to the period of economic and social development in ancient Rome. Studying in the ancient Spring and Autumn and Warring States Period in China can also be regarded as a prototype of the development of cross-border education in China. Driven by the deepening of economic and cultural exchanges between countries in the world, the development of higher education teaching has gradually entered into a complex and diversified development process. Research on the status quo of cross-border higher education has gradually attracted the attention of staff in the field of education.

\section{A Brief Analysis of Cross-Border Higher Education}

\subsection{The Basic Connotation of Cross-Border Higher Education}

The establishment of the basic connotation of cross-border education has a long history of development. Under the premise of the continuous development of economic integration in the world, the importance of cross-border education activities is gradually becoming familiar to college teachers [2]. In the current research field of education and teaching in the world, the research content of the so-called cross-border education research is mainly complicated and cumbersome. The setting of course content, the development of teaching and research activities, and the cultivation of intercultural communication skills of teaching staff are all highly encompassed in the research coverage of cross-border education. Some staff members in the research field of cross-cultural communication topics have also combined the development of cross-border education research work into one of the components of the international cultural localization development trend under the premise of the development of domestic education and teaching. Cross-border education research is a research area of cross-cultural communication research. Teachers, students and cross-border cultural projects are the main research objects of cross-border higher education.

According to the data and information provided by the National Bureau of Education of China, the acceptance of the basic concept of cross-border education by the United Nations Educational and Teaching Organization in the world began at the beginning of the 21st century. Before that, all the proposals related to the definition of the basic connotation of cross-border education were based on the research perspective of speculation and prediction.

\subsection{Main Features of Cross-Border Higher Education}

As an educational research activity based on practical teaching methods, the development of cross-border higher education research has gradually become a solid driving force for the development of higher education institutions' own teaching career. Looking at the current status of the work of European and American countries and Western capitalist education research, the development of cross-border education research work mainly has several development characteristics that are more prominent. 
First, cross-border education is based on cultural communication between the two countries, so cross-border education research work is fully transnational. For example, in the process of actual teaching work, educators and learners of cultural content come from different countries and regions. Teachers usually make up for the shortcomings and deficiencies in their teaching work by taking advantage of the advantages of other countries' teaching resources in practical teaching.

Secondly, the development of cross-border education and teaching work is the random flow of cultural content and knowledge elements between different national borders. For example, the flow of scholars in different countries, the exchange and learning of educators in different national boundaries, and the mutual transfer of teaching resources between different educational regions are representative expressions of cross-border education mobility.

On this basis, the development of cross-border education research work has a certain degree of diversity and characteristics. In terms of teaching mode, the development of cross-border education research can be carried out in a state-based mode as a supporter, or through a joint approach with domestic higher education units. Under the influence and influence of the continuous maturity of Internet information transmission technology, virtual network universities and trial operation teaching centers have gradually become popular teaching models. The providers of cross-border education and teaching resources also have the characteristics of different levels of diversity.

\section{The Main Problems in the Current Study of Cross-Border Higher Education}

Under the background of the rapid development of information technology, the global trend of internationalization is more obvious. Focusing on cross-border higher education, there are still some new development problems that should attract the attention of policy makers.

\subsection{The Division of Sovereignty in Educational Research}

The development of cross-border higher education research involves the integration of cultural content and teaching resources between different countries and regions. The competition and division of educational sovereignty, as one of the components of the country's basic sovereignty, has become the highest right of the country to carry out cross-border education activities. However, in the current process of opening cross-border educational activities worldwide, there are serious gaps in economic and cultural levels between developed and developing countries. This has led to the implementation of cross-border education activities, which threatened and shocked the comprehensive education system of economically backward countries to a certain extent [3]. A large number of cross-border teaching resources and the influx of foreign cultural teaching content directly impacted the manipulation sovereignty of education and teaching 
activities within the designated countries. Even for some developing countries with serious economic lags, the influx of cross-border educational content in foreign countries has directly reduced their leading ability in education control.

\subsection{Cultural Security Issues of Educational Content}

Through in-depth study of the basic content of cross-border education and teaching, we can find that the development of education and teaching activities can directly affect the life values of residents in a country and region. Some western developed capitalist countries often attempt to inculcate the political and economic values that their people generally follow through the development of cross-border education and teaching activities to developing countries with relatively backward economic development levels. Over time, the development of cross-border cultural exchanges and educational activities has even become a hegemonic tool for the conscious minds of some western capitalist countries. If based on the educational perspective of developing countries, the influx of foreign cross-border education content directly dilutes the influence of local culture on the domestic people.

\subsection{Equity in Educational and Teaching Activities}

At present, cross-border education and teaching activities carried out worldwide are affected by the level of economic and cultural development of various countries, and there are serious inequality implementation phenomena. Developed countries often have sufficient dominance in the entire cross-border education activities. Cross-border teaching resources that are transmitted to developing countries often fail to adequately address the actual demands of developing countries for cross-border education and cross-cultural communication. The selection of the content of intercultural communication courses and the setting of teachers' actual teaching level in developing countries are all unilaterally set by the developed countries. Tuition fees that seriously exceed the average level of education expenditure in the country directly impede poor students in developing countries from receiving equal cross-border professional education. On the basis of the sub-division, the host country of the cross-border education and teaching work, due to attracting and recruiting a large number of international students, will inevitably reduce the supply of teaching resources to the same professional aspects of the students in different degrees.

\subsection{The Public Welfare of Cross-Border Education}

In the historical period of social development in the past, the development of education and teaching was often a non-profit public welfare public utility. However, the development of cross-border education and teaching research, the providers of its financial resources, mostly for the education and teaching institutions for the purpose of profit-making in the society, private colleges and so on. Most of the cross-border teaching work is carried out in the form of 
cross-border withdrawal and commercial activities. Throughout the current cross-border educational activities around the world, the international students' tuition fees and the payment methods for the purchase of teaching resources are still based on the existence of commercial capital flows [4]. This directly provides a legitimate profit channel for a large number of profitable teaching units. After the first year of social development of knowledge-based economy in the 21 st century, more and more cross-border teaching institutions with profit as their main business purpose poured into the world teaching market, directly impacting the original intention of traditional cross-border education with public welfare as its main teaching purpose.

\section{Development Trend of Cross-Border Education Relying on Network Information in Future Society}

It is believed that in the future society where the depth of international cultural exchanges is intensifying, relying on the technological advantages of network information can make it more convenient for contemporary students to accept. As a network participation group with rich network knowledge accumulation, college students are more willing to accept the network education method than the traditional classroom teaching mode. In online education, the status of teachers and students is closer to that of friends, education resources are fully open, and educational means are more abundant. All of this makes online education more attractive. Learning on such a platform, students will have a stronger interest in learning and better learning. From the actual trend of teaching expenditures in the education departments of various countries, it can be seen that the implementation of cross-border education research activities has great potential for development [5].

In order to better meet the development needs of the teaching sponsors for profit and better train the professional education talents of cross-cultural communication, the traditional higher education institutions will integrate with the specialized cross-border teaching institutions, improve their teaching standards while complementing each other, and ultimately achieve the long-term goal of stable development of cross-border education and teaching.

\section{Conclusion}

Internationalization has become an important symbol of the development of higher education in our time. Although there are still some problems in the development of cross-border education, teachers as the main body of teaching should adapt to the new development trend of higher education in advance, fully understand the connotation and basic characteristics of cross-border higher education, and effectively improve their own quality and teaching level. In the context of internationalization, teachers can achieve fruitful results in the research of teaching status in combination with the actual teaching plans so that China will soon be in line with the internationalization of higher education in the world's advanced countries. 


\section{Conflicts of Interest}

The author declares no conflicts of interest regarding the publication of this paper.

\section{References}

[1] Guo, Y. and Guo, S. (2017) Internationalization of Canadian Higher Education: Discrepancies between Policies and International Student Experiences. Studies in Higher Education, 42, 851-868. https://doi.org/10.1080/03075079.2017.1293874

[2] Kosmützky, A. and Putty, R. (2016) Transcending Borders and Traversing Boundaries: A Systematic Review of the Literature on Transnational, Offshore, Cross-Border, and Borderless Higher Education. Journal of Studies in International Education, 20, 8-33. https://doi.org/10.1177/1028315315604719

[3] Amaral, A., Tavares, O., Cardoso, S., et al. (2016) Shifting Institutional Boundaries through Cross-Border Higher Education. Journal of Studies in International Education, 20, 48-60. https://doi.org/10.1177/1028315315587108

[4] Faist, T. (2016) Cross-Border Migration and Social Inequalities. Annual Review of Sociology, 42, 323-346. https://doi.org/10.1146/annurev-soc-081715-074302

[5] He, L. and Wilkins, S. (2018) Achieving Legitimacy in Cross-Border Higher Education: Institutional Influences on Chinese International Branch Campuses in South East Asia. Journal of Studies in International Education, 22, 179-197.

https://doi.org/10.1177/1028315317738774 